\title{
Influence of sugammadex versus neostigmine for neuromuscular block reversal on the incidence of postoperative pulmonary complications: a meta-analysis of randomized controlled trials
}

\author{
Jia-Feng Wang ${ }^{1+}$, Zhen-Zhen Zhao ${ }^{\dagger}$, Zheng-Yu Jiang ${ }^{1}$, Hui-Xing Liu² and Xiao-Ming Deng ${ }^{1 *}$
}

\begin{abstract}
Background: The influence of sugammadex for reversal of neuromuscular block (NMB) on postoperative pulmonary complications (PPCs), compared with neostigmine, remains to be determined. We performed a meta-analysis of randomized controlled trials (RCTs) to compare the incidence of PPCs between patients who received sugammadex versus neostigmine.

Methods: Relevant studies were obtained by searching the PubMed, Embase, and Cochrane Library databases. A random effects model incorporating the potential heterogeneity was used to pool the results.

Results: Fourteen RCTs including 1478 adult patients who underwent surgeries with general anesthesia were included, and of these, 753 received sugammadex and 725 received neostigmine for reversal of NMB. The pooled results showed that sugammadex was associated with a lower risk of overall PPCs compared to neostigmine (odds ratio [OR]: 0.62, 95\% confidence interval [Cl]: 0.43-0.89, $p=0.01 ; P^{2}=0 \%$ ). This finding remained consistent after exclusion of two studies with potential overlapping events (OR: 0.58 , 95\% Cl: $0.36-0.96, p=0.03 ; P^{2}=9 \%$ ). Stratified analyses according to the categories of PPCs showed that sugammadex was associated with a significantly lower risk of postoperative respiratory failure (OR: $0.60,95 \% \mathrm{Cl}: 0.38-0.97, p=0.04 ; P^{2}=0 \%$ ) but not of postoperative pulmonary infection (OR: 0.79 , $p=0.71$ ), atelectasis (OR: $0.78, p=0.33$ ), or pneumothorax (OR: $0.87, p=0.79$ ).
\end{abstract}

Conclusions: Compared with neostigmine, the use of sugammadex for reversal of NMB was associated with a lower risk of PPCs, mainly due to a lower incidence of postoperative respiratory failure with the use of sugammadex.

Keywords: Neuromuscular block, Postoperative pulmonary complications, Sugammadex, Neostigmine, Meta-analysis

\footnotetext{
*Correspondence: deng_x@yahoo.com

${ }^{\dagger}$ Jia-Feng Wang and Zhen-Zhen Zhao contributed equally to this work.

${ }^{1}$ Faculty of Anesthesiology, Changhai Hospital, Naval Medical University, 168 Changhai Road, Shanghai 200433, China

Full list of author information is available at the end of the article
}

(C) The Author(s). 2021 Open Access This article is licensed under a Creative Commons Attribution 4.0 International License, which permits use, sharing, adaptation, distribution and reproduction in any medium or format, as long as you give appropriate credit to the original author(s) and the source, provide a link to the Creative Commons licence, and indicate if changes were made. The images or other third party material in this article are included in the article's Creative Commons licence, unless indicated otherwise in a credit line to the material. If material is not included in the article's Creative Commons licence and your intended use is not permitted by statutory regulation or exceeds the permitted use, you will need to obtain permission directly from the copyright holder. To view a copy of this licence, visit http://creativecommons.org/licenses/by/4.0/ The Creative Commons Public Domain Dedication waiver (http://creativecommons.org/publicdomain/zero/1.0/) applies to the data made available in this article, unless otherwise stated in a credit line to the data. 


\section{Background}

Currently, medications that provide a neuromuscular block (NMB) are routinely administered in major surgeries and procedures to facilitate airway intubation and maintain surgical status (Zafirova \& Dalton, 2018; Stauble \& Blobner, 2020). Although reversal agents are applied to eliminate NMB after surgery, residual NMB may remain and has been associated with an increased risk of postoperative pulmonary complications (PPCs), such as hypoxia, atelectasis, pulmonary infection, etc. (Miskovic \& Lumb, 2017; Raval et al., 2020). With a varying incidence of $1-$ $23 \%$, PPCs have been correlated to higher short-term and long-term mortality in patients after major surgical procedures (Raval et al., 2020; Cammu, 2020). Therefore, effective strategies to reduce the incidence of residual NMBrelated PPCs are important to improve the overall prognosis of patients after major surgeries.

Conventionally, neostigmine, an acetylcholinesterase inhibitor, is used as a NMB reversal drug (Haerter \& Eikermann, 2016). However, accumulating evidence suggests that the NMB reversal efficacy of neostigmine is less than optimal, particular for deep NMB (Dubois \& Mulier, 2013). Sugammadex, a gamma-cyclodextrin that specifically binds to rocuronium, has been shown to confer faster and more complete reversal of NMB as compared with neostigmine (Carron et al., 2016a; Hristovska et al., 2017; Hristovska et al., 2018; Won et al., 2016). Additionally, the use of sugammadex is suggested to be associated with fewer overall postoperative adverse events compared with neostigmine (Hristovska et al., 2017), leading to accelerated postoperative discharge of patients after general anesthesia (Carron et al., 2020; Carron et al., 2017). However, clinical studies comparing the incidence of PPCs after NMB reversal with sugammadex versus neostigmine have provided inconsistent results (Schaller et al., 2010; Geldner et al., 2012; Carron et al., 2013; Brueckmann et al., 2015; Koyuncu et al., 2015; Unal et al., 2015; Hakimoglu et al., 2016; Agha et al., 2017; Yagan et al., 2017; Alday et al., 2019; Claroni et al., 2019; Ba et al., 2020; Lee et al., 2020; Togioka et al., 2020). For example, some previous randomized controlled trials (RCTs) showed that sugammadex is associated with a reduced risk of PPCs as compared with neostigmine (Carron et al., 2013; Unal et al., 2015), while other studies did not show a significant difference regarding the incidence of PPCs among patients allocated to the two drugs (Schaller et al., 2010; Geldner et al., 2012; Brueckmann et al., 2015; Koyuncu et al., 2015; Hakimoglu et al., 2016; Agha et al., 2017; Yagan et al., 2017; Alday et al., 2019; Claroni et al., 2019; Ba et al., 2020; Lee et al., 2020; Togioka et al., 2020). Moreover, the outcome of PPCs was rarely observed in previous meta-analyses comparing the efficacy and safety between sugammadex and neostigmine for reversal of NMB
(Carron et al., 2016a; Hristovska et al., 2017; Hristovska et al., 2018). Therefore, it remains undetermined whether sugammadex is superior to neostigmine with regard to the risk of PPCs. In view of the limited sample sizes in previous RCTs, which may cause potential statistical inadequacy, we aimed to compare the influence of NMB reversal with sugammadex or neostigmine on the risk of PPCs after general anesthesia via a meta-analysis.

\section{Methods}

The PRISMA (Preferred Reporting Items for Systematic Reviews and Meta-Analyses) statement (Moher et al., 2009) and the Cochrane Handbook guidelines (Higgins \& Green, 2011) were followed during the designing and implementation of this study.

\section{Search strategy}

The PubMed, Embase, and Cochrane Library (Cochrane Center Register of Controlled Trials) databases were searched from inception to April 5, 2020 for relevant studies with a combined strategy of (1) "sugammadex" OR "selective relaxant binding agent" OR "SRBA" OR "org 25969" OR "bridion" and (2) "neostigmine". This extensive search strategy was used to avoid missing any potentially relevant RCTs. Only clinical studies published in English or Chinese were considered. The references of related reviews and original articles were also searched as a complementation.

\section{Study selection}

Parallel-group RCTs published as peer-reviewed articles in English or Chinese were considered for this metaanalysis. The inclusion criteria according to the PICO principle were (1) Patients: adult patients undergoing surgeries with general anesthesia with NMB were included; (2) Intervention: sugammadex was used as intervention for NMB reversal; (3) Comparison: neostigmine was used as control for NMB reversal; and (4) Outcomes: reporting of the incidence of PPCs during the perioperative periods. PPCs were defined in accordance with previous consensus of multiple studies, which generally included respiratory failure, respiratory infection, atelectasis, pneumothorax, pleural effusion, etc. (Miskovic \& Lumb, 2017; Tao et al., 2014; Jammer et al., 2015). The definition of postoperative respiratory failure was in accordance with the European Perioperative Clinical Outcome criteria, which included postoperative $\mathrm{PaO} 2<$ $8 \mathrm{kPa}(60 \mathrm{mmHg})$ on room air, a PaO2:FIO2 ratio $<40$ $\mathrm{kPa}(300 \mathrm{mmHg})$, or arterial oxyhemoglobin saturation measured with pulse oximetry $<90 \%$ and requiring oxygen therapy (Miskovic \& Lumb, 2017). Reviews, studies including children or neonates, preclinical studies, observational studies, and repeated reports were excluded. 


\section{Data extraction and quality assessment}

The literature search, data extraction, and quality evaluation were performed by two authors independently. Any disagreement was resolved by consensus between the two authors. We extracted data regarding study information (first author, publication year, and study country), study design (blind or open-label), patient and surgery characteristics (number of participants, mean age, gender, and surgery type), agent for NMB, and dose of sugammadex or neostigmine. The primary outcome of the meta-analysis was the incidence of overall PPCs, and the secondary outcomes were the incidences of individual categories of PPCs, including postoperative respiratory failure, respiratory infection, atelectasis, pneumothorax, pleural effusion, etc.. For studies with unclear outcome data, the corresponding authors of the original studies were contacted via email for further clarification. Quality evaluation was achieved using the Cochrane's Risk of Bias Tool (Higgins \& Green, 2011), according to the following aspects (1) random sequence generation, (2) allocation concealment, (3) blinding of participants and personnel, (4) blinding of outcome assessors, (5) incomplete outcome data, (6) selective outcome reporting, and (7) other potential bias.

\section{Statistical analysis}

The incidence of PPCs in each arm was evaluated via the odds ratio (OR) and its 95\% confidence interval (CI). We used the Cochrane's $Q$ test to detect the heterogeneity, and significant heterogeneity was suggested if $p<0.10$ (Higgins \& Thompson, 2002). The $I^{2}$ statistic was also calculated, and an $I^{2}>50 \%$ reflected significant heterogeneity. Pooled analyses were calculated using a random effects model, because this method incorporates the influence of potential heterogeneity and provides a more generalized result (Higgins \& Green, 2011). Sensitivity analyses based on the omission of one study at a time were performed to evaluate the stability of the metaanalysis result. Stratified analyses were performed to evaluate the risk of each category of PPCs in patients in the sugammadex or neostigmine reversal group. Publication bias was evaluated by visual inspection of funnel plots and the Egger's regression asymmetry test (Egger et al., 1997). Values of $p<0.05$ were considered statistically significant. The RevMan (Version 5.1; Cochrane, Oxford, UK) and Stata software (Version 12.0; Stata, College Station, TX, USA) were applied for statistical analyses.

\section{Results}

\section{Search results}

In total, 1037 articles were obtained through the initial database searches. After exclusion of duplicate studies, 798 articles were screened. Among them, 733 articles were subsequently excluded based on titles and abstracts, primarily because these studies were not relevant. Among the 65 potentially relevant articles, 51 were further excluded after full-text review based on reasons listed in Fig. 1. Finally, 14 RCTs were included (Schaller et al., 2010; Geldner et al., 2012; Carron et al., 2013; Brueckmann et al., 2015; Koyuncu et al., 2015; Unal et al., 2015; Hakimoglu et al., 2016; Agha et al., 2017; Yagan et al., 2017; Alday et al., 2019; Claroni et al., 2019; Ba et al., 2020; Lee et al., 2020; Togioka et al., 2020).

\section{Study characteristics}

Table 1 presents the characteristics of the included studies. Overall, 14 RCTs including 1478 adult patients who underwent surgeries with general anesthesia were included. Of these, 753 were given sugammadex, and 725 were given neostigmine for reversal of NMB. These studies were published between 2010 and 2020 and performed in the USA, Germany, Italy, Spain, Turkey, Malaysia, South Korea, and China. The adult patients underwent various surgeries, including major abdominal surgery, laparoscopic surgery, arthroscopic surgery, extremity surgery, thoracoscopic lung cancer resection, robot-assisted radical cystectomy for bladder cancer, and surgery for obstructive sleep apnea. The sample sizes in the RCTs varied from 40 to 200. In all of the included studies, rocuronium was used for NMB. The doses of sugammadex and neostigmine varied from 0.0625 to $\sim 4$ $\mathrm{mg} / \mathrm{kg}$ and 5 to $\sim 85 \mu \mathrm{g} / \mathrm{kg}$, respectively.

\section{Data quality}

Table 2 and Fig. 2 show the details of the study quality evaluation. Six of the included RCTs were double blind (Schaller et al., 2010; Geldner et al., 2012; Brueckmann et al., 2015; Koyuncu et al., 2015; Agha et al., 2017; Claroni et al., 2019), three were single blind (Yagan et al., 2017; Alday et al., 2019; Lee et al., 2020), and the rest did not apply blinding. Methods of random sequence generation were reported in 11 studies (Schaller et al., 2010; Geldner et al., 2012; Carron et al., 2013; Brueckmann et al., 2015; Hakimoglu et al., 2016; Agha et al., 2017; Yagan et al., 2017; Claroni et al., 2019; Ba et al., 2020; Lee et al., 2020; Togioka et al., 2020), and information for allocation concealment was reported in 9 studies (Schaller et al., 2010; Carron et al., 2013; Brueckmann et al., 2015; Unal et al., 2015; Agha et al., 2017; Yagan et al., 2017; Claroni et al., 2019; Lee et al., 2020; Togioka et al., 2020). The overall quality scores varied from 3 to 7 .

\section{Meta-analysis results}

Two studies reported the incidence rates for individual categories of PPCs rather than the total number of patients with PPCs in each arm (Brueckmann et al., 2015; Alday et al., 2019). For these studies, potential overlapping of the PPC events could have occurred in the same 


\section{PRISMA FLOW DIAGRAM}
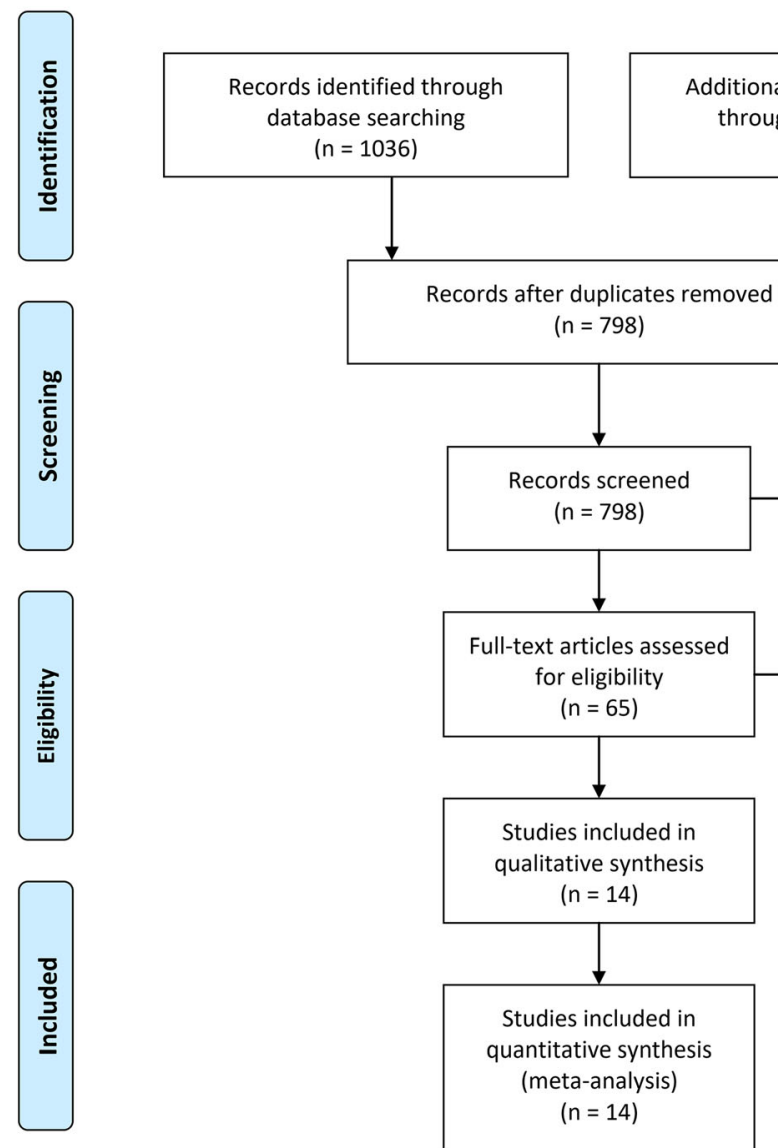

Additiona records identified through other sources $(n=1)$
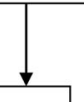

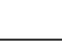
Records excluded $(n=733)$

Not relevant studies 676

Not RCTs 38

Reviews or editorials 19

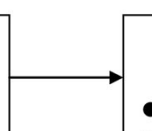

Full-text articles excluded with reasons $(n=51)$

- Study in children $n=1$

- Study with a combination of UG and NEO $n=1$

- PPC outcomes not reported or not occur $n=49$

Fig. 1 Flow chart of literature search

patients. We contacted the corresponding authors for further clarification. However, no response was received. For these two studies (Brueckmann et al., 2015; Alday et al., 2019), we first simply added the numbers of each category of PPC as the overall number of PPCs and included these totals in the main meta-analysis; then, sensitivity analysis with exclusion of these two studies with patients who experienced potentially overlapping PPCs were performed.

No significant heterogeneity was detected for the main meta-analysis ( $p$ for Cochrane's Q test $=0.45, I^{2}=0 \%$ ). The pooled results with a random effects model showed that sugammadex was associated with a significantly lower risk of overall PPCs compared with neostigmine (14 studies; OR: 0.62, 95\% CI: 0.43-0.89, $p=0.01$; Fig. 3A). Sensitivity analyses with omission of one study at a time showed similar results (OR: $0.55-0.68$, all $p<0.05$ ). Additionally, exclusion of the two studies including patients with potentially overlapping PPCs did not significantly change the results (12 studies; OR: $0.58,9 \%$ CI: 0.36-0.96, $p=0.03 ; \mathrm{I}^{2}=9 \%$; Fig. 3B).
Stratified analyses according to the categories of PPCs showed that sugammadex was associated with a significantly lower risk of postoperative respiratory failure (14 studies; OR: $0.60,95 \%$ CI: $0.38-0.97, p=0.04 ; I^{2}=0 \%$; Fig. 4) but not of postoperative respiratory infection (3 studies; OR: $0.79, p=0.71$ ), atelectasis (2 studies; OR: $0.78, p=0.33$ ), or pneumothorax (1 study; OR: $0.87, p=$ $0.79)$.

\section{Publication bias}

The funnel plots were symmetrical, suggesting low risk of publication bias (Fig. 5). Egger's regression tests showed similar results $(p=0.65)$.

\section{Discussion}

In this meta-analysis of 14 RCTs, we found that compared with the conventional NMB reversal drug neostigmine, sugammadex was associated with a significantly lower risk of overall PPCs. Stratified analyses showed that patients who received sugammadex had a significantly reduced risk of postoperative respiratory failure 
Table 1 Characteristics of the included RCTs

\begin{tabular}{|c|c|c|c|c|c|c|c|c|c|c|}
\hline \multirow[t]{2}{*}{ Study } & \multirow[t]{2}{*}{ Country } & \multirow[t]{2}{*}{ Design } & \multirow[t]{2}{*}{$\begin{array}{l}\text { Patients and } \\
\text { surgeries }\end{array}$} & \multirow[t]{2}{*}{$\begin{array}{l}\text { Sample } \\
\text { size }\end{array}$} & \multirow{2}{*}{$\begin{array}{l}\text { Mean } \\
\text { age } \\
\text { years }\end{array}$} & \multirow{2}{*}{$\begin{array}{l}\text { Male } \\
\%\end{array}$} & \multirow[t]{2}{*}{$\begin{array}{l}\text { Neuromuscular } \\
\text { blocking agent }\end{array}$} & \multirow[t]{2}{*}{$\begin{array}{l}\text { Sugammadex } \\
\text { dose }\end{array}$} & \multirow[t]{2}{*}{$\begin{array}{l}\text { Neostigmine } \\
\text { dose }\end{array}$} & \multirow{2}{*}{$\begin{array}{l}\text { Secondary } \\
\text { PPCs } \\
\text { reported }^{\text {a }}\end{array}$} \\
\hline & & & & & & & & & & \\
\hline $\begin{array}{l}\text { Schaller } \\
\text { et al., } 2010\end{array}$ & Germany & $R, D B$ & $\begin{array}{l}\text { ASA I-III, various } \\
\text { surgery type }\end{array}$ & 94 & 42 & 54 & Rocuronium & $\begin{array}{l}0.0625,0.125 \\
0.25,0.5, \text { or } 1.0 \\
\mathrm{mg} / \mathrm{kg}\end{array}$ & $\begin{array}{l}5,8,15,25, \text { or } \\
40 \mu \mathrm{mg} / \mathrm{kg}\end{array}$ & A \\
\hline $\begin{array}{l}\text { Geldner } \\
\text { et al., } 2012\end{array}$ & Germany & $R, D B$ & $\begin{array}{l}\text { ASA I-III, laparoscopic } \\
\text { surgery }\end{array}$ & 133 & 51 & 31 & Rocuronium & 4 mg/kg & $50 \mu \mathrm{g} / \mathrm{kg}$ & A \\
\hline $\begin{array}{l}\text { Carron et al., } \\
2013\end{array}$ & Italy & $R$ & $\begin{array}{l}\text { ASA I-III, obese } \\
\text { patients for } \\
\text { laparoscopic removal } \\
\text { of adjustable gastric } \\
\text { banding }\end{array}$ & 40 & 43 & 30 & Rocuronium & 4 mg/kg & $70 \mu \mathrm{g} / \mathrm{kg}$ & A \\
\hline $\begin{array}{l}\text { Koyuncu } \\
2014\end{array}$ & Turkey & $R, D B$ & $\begin{array}{l}\text { ASA I-\|, extremity } \\
\text { surgery }\end{array}$ & 100 & 27 & 54 & Rocuronium & $2 \mathrm{mg} / \mathrm{kg}$ & $70 \mu \mathrm{g} / \mathrm{kg}$ & A \\
\hline $\begin{array}{l}\text { Brueckmann } \\
\text { et al., } 2015\end{array}$ & USA & $R, D B$ & $\begin{array}{l}\text { ASA I-III, elective } \\
\text { laparoscopic or open } \\
\text { abdominal surgery }\end{array}$ & 151 & 57 & 60 & Rocuronium & 2 or 4 mg/kg & $\begin{array}{l}17.1-84.8 \mu \mathrm{g} / \\
\mathrm{kg}\end{array}$ & $A, B$ \\
\hline $\begin{array}{l}\text { Unal et al., } \\
2015\end{array}$ & Turkey & $\mathrm{R}$ & $\begin{array}{l}\text { ASA I-II, surgery for } \\
\text { OSA }\end{array}$ & 74 & 46 & NR & Rocuronium & $2 \mathrm{mg} / \mathrm{kg}$ & $40 \mu \mathrm{g} / \mathrm{kg}$ & A \\
\hline $\begin{array}{l}\text { Hakimoglu } \\
\text { et al., } 2016\end{array}$ & Turkey & $R$ & $\begin{array}{l}\text { ASA I-II, arthroscopic } \\
\text { surgery }\end{array}$ & 60 & 34 & 65 & Rocuronium & 4 mg/kg & $50 \mu \mathrm{g} / \mathrm{kg}$ & A \\
\hline Loh 2017 & Malaysia & $\mathrm{R}, \mathrm{DB}$ & $\begin{array}{l}\text { ASA I-III, various } \\
\text { surgery type }\end{array}$ & 120 & 44 & 48 & Rocuronium & $2 \mathrm{mg} / \mathrm{kg}$ & $20 \mu \mathrm{g} / \mathrm{kg}$ & $A$ \\
\hline $\begin{array}{l}\text { Yagan et al., } \\
2017\end{array}$ & Turkey & $R, S B$ & $\begin{array}{l}\text { ASA I-II, various } \\
\text { surgery type }\end{array}$ & 98 & 40 & 65 & Rocuronium & $2 \mathrm{mg} / \mathrm{kg}$ & $50 \mu \mathrm{g} / \mathrm{kg}$ & A \\
\hline $\begin{array}{l}\text { Alday et al., } \\
2019\end{array}$ & Spain & $R, S B$ & $\begin{array}{l}\text { ASA I-IV, major } \\
\text { abdominal surgery }\end{array}$ & 126 & 68 & 51 & Rocuronium & 4 mg/kg & $40 \mu \mathrm{g} / \mathrm{kg}$ & $A, B, C$ \\
\hline $\begin{array}{l}\text { Claroni et al., } \\
2019\end{array}$ & Italy & $\mathrm{R}, \mathrm{DB}$ & $\begin{array}{l}\text { ASA I-III, robot- } \\
\text { assisted radical cystec- } \\
\text { tomy for bladder } \\
\text { cancer }\end{array}$ & 109 & 62 & 83 & Rocuronium & 2 mg/kg & $40 \mu \mathrm{g} / \mathrm{kg}$ & $A$ \\
\hline $\begin{array}{l}\text { Togioka } \\
\text { et al., } 2020\end{array}$ & USA & $\mathrm{R}, \mathrm{OL}$ & $\begin{array}{l}\text { ASA I-IV, various } \\
\text { surgery type }\end{array}$ & 200 & 75 & 46 & Rocuronium & 2 mg/kg & 70 mg/kg & $A, B, C, D$ \\
\hline $\begin{array}{l}\text { Lee et al., } \\
2020\end{array}$ & $\begin{array}{l}\text { South } \\
\text { Korea }\end{array}$ & $R, S B$ & $\begin{array}{l}\text { ASA I-II, elective } \\
\text { laparoscopic } \\
\text { cholecystectomy }\end{array}$ & 73 & 56 & 48 & Rocuronium & 4 mg/kg & $40 \mu \mathrm{g} / \mathrm{kg}$ & A \\
\hline $\begin{array}{l}\text { Ba et al., } \\
2020\end{array}$ & China & $\mathrm{R}$ & $\begin{array}{l}\text { ASA I-II, radical } \\
\text { resection of lung } \\
\text { cancer under } \\
\text { thoracoscope }\end{array}$ & 100 & 50 & 51 & Rocuronium & 2 mg/kg & $2 \mathrm{mg}$ & A \\
\hline
\end{tabular}

$R C$ Trandomized controlled trial; $R$ randomized; $D B$ double-blind; $S B$ single-blind; OL open-label; $A S A$ American Society of Anesthesiology; OSA obstructive sleep apnea.

Indicators for secondary PPCs: A, respiratory failure; B, respiratory infection; C, atelectasis; and D, pneumothorax

compared with those who received neostigmine, while the incidences of other PPCs, including pulmonary infection, atelectasis, and pneumothorax, did not differ significantly between the groups. These findings suggest that NMB reversal with sugammadex was superior to that with neostigmine in providing lower incidences of overall PPCs and postoperative respiratory failure.

To the best of our knowledge, our study is the first meta-analysis specifically investigating the potential influences of NMB reversal by sugammadex or neostigmine on the incidence of PPCs in patients after general surgery.
We found that sugammadex was effective at reducing overall PPCs compared with neostigmine. These results were further confirmed by sensitivity analyses, while stratified analyses suggested the benefit of sugammadex for PPCs as compared to neostigmine was mainly driven by the lower risk of postoperative respiratory failure. Interestingly, 12 of the included RCTs did not show a significant difference regarding the incidence of PPCs between patients who received sugammadex versus neostigmine (Schaller et al., 2010; Geldner et al., 2012; Brueckmann et al., 2015; Koyuncu et al., 2015; Hakimoglu et al., 2016; 
Table 2 Quality evaluation with Cochrane's risk of bias tool

\begin{tabular}{|c|c|c|c|c|c|c|c|c|}
\hline & $\begin{array}{l}\text { Sequence } \\
\text { generation }\end{array}$ & $\begin{array}{l}\text { Allocation } \\
\text { concealment }\end{array}$ & $\begin{array}{l}\text { Blinding of } \\
\text { participants and } \\
\text { personnel }\end{array}$ & $\begin{array}{l}\text { Blinding of } \\
\text { outcome } \\
\text { assessment }\end{array}$ & $\begin{array}{l}\text { Incomplete } \\
\text { outcome data }\end{array}$ & $\begin{array}{l}\text { Selective } \\
\text { outcome } \\
\text { reporting }\end{array}$ & $\begin{array}{l}\text { Other } \\
\text { potential } \\
\text { threats }\end{array}$ & Total \\
\hline $\begin{array}{l}\text { Schaller } \\
\text { et al., } 2010\end{array}$ & Low & Low & Low & Low & Low & Low & Unclear & 6 \\
\hline $\begin{array}{l}\text { Geldner } \\
\text { et al., } 2012\end{array}$ & Low & Unclear & Low & Low & Low & Low & Unclear & 5 \\
\hline $\begin{array}{l}\text { Carron et al., } \\
2013\end{array}$ & Low & Low & Unclear & Unclear & Low & Low & Unclear & 4 \\
\hline $\begin{array}{l}\text { Koyuncu } \\
2014\end{array}$ & Unclear & Unclear & Low & Low & Low & Low & Unclear & 4 \\
\hline $\begin{array}{l}\text { Brueckmann } \\
\text { et al., } 2015\end{array}$ & Low & Low & Low & Low & Low & Low & Low & 7 \\
\hline $\begin{array}{l}\text { Unal et al., } \\
2015\end{array}$ & Unclear & Low & Unclear & Unclear & Low & Low & Unclear & 3 \\
\hline $\begin{array}{l}\text { Hakimoglu } \\
\text { et al., } 2016\end{array}$ & Low & Unclear & Unclear & Unclear & Low & Low & Unclear & 3 \\
\hline Loh 2017 & Low & Low & Low & Low & Low & Low & Unclear & 6 \\
\hline $\begin{array}{l}\text { Yagan et al., } \\
2017\end{array}$ & Low & Low & Low & High & Low & Low & Unclear & 5 \\
\hline $\begin{array}{l}\text { Alday et al., } \\
2019\end{array}$ & Unclear & Unclear & Low & High & Low & Low & Unclear & 3 \\
\hline $\begin{array}{l}\text { Claroni et al., } \\
2019\end{array}$ & Low & Low & Low & Low & Low & Low & Unclear & 6 \\
\hline $\begin{array}{l}\text { Togioka } \\
\text { et al., } 2020\end{array}$ & Low & Low & High & High & Low & Low & Low & 4 \\
\hline $\begin{array}{l}\text { Lee et al., } \\
2020\end{array}$ & Low & Low & High & Low & Low & Low & Unclear & 5 \\
\hline $\begin{array}{l}\text { Ba et al., } \\
2020\end{array}$ & Low & Unclear & Unclear & Unclear & Low & Low & Unclear & 3 \\
\hline
\end{tabular}

Agha et al., 2017; Yagan et al., 2017; Alday et al., 2019; Claroni et al., 2019; Ba et al., 2020; Lee et al., 2020; Togioka et al., 2020), which may indicate the general inadequacy of the statistical power in these RCTs to detect a significant effect on the PPC incidence. Although many factors have been related to the incidence of PPCs, residual NMB has been suggested to be one of the major determinants for the pathogenesis of PPCs (Cammu, 2020). Cohort studies have confirmed clear associations between residual NMB and the risks of various types of PPCs, such as upper airway obstruction, hypoxemia, atelectasis, and pneumonia (Bulka et al., 2016; Murphy et al., 2004; Murphy et al., 2008; Stawicki \& Gessner, 2018). Furthermore, it has been suggested that even slight residual

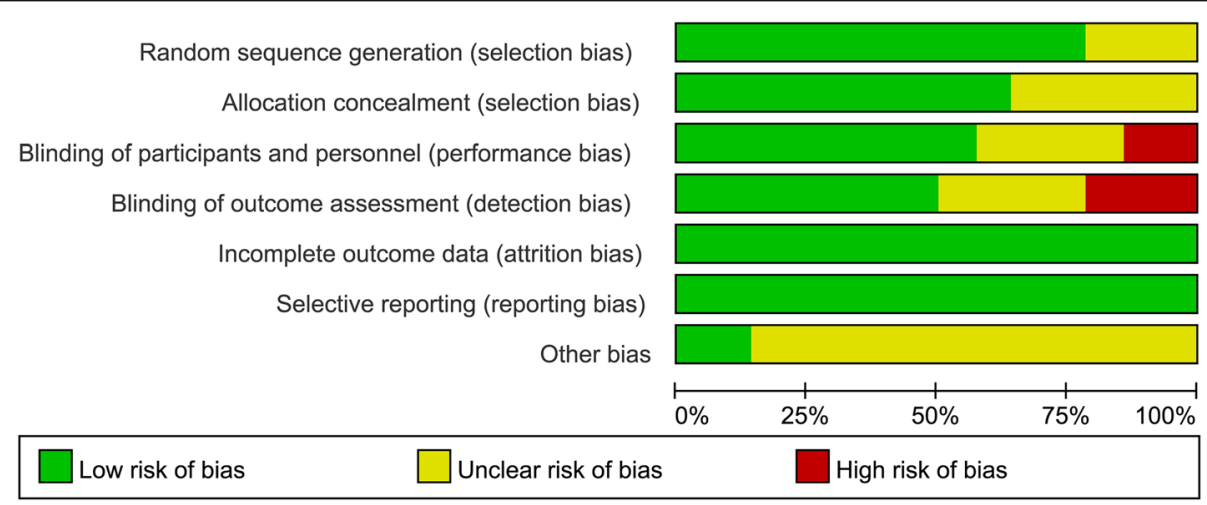

Fig. 2 Summary of study quality evaluation using Cochrane's risk of bias tool 

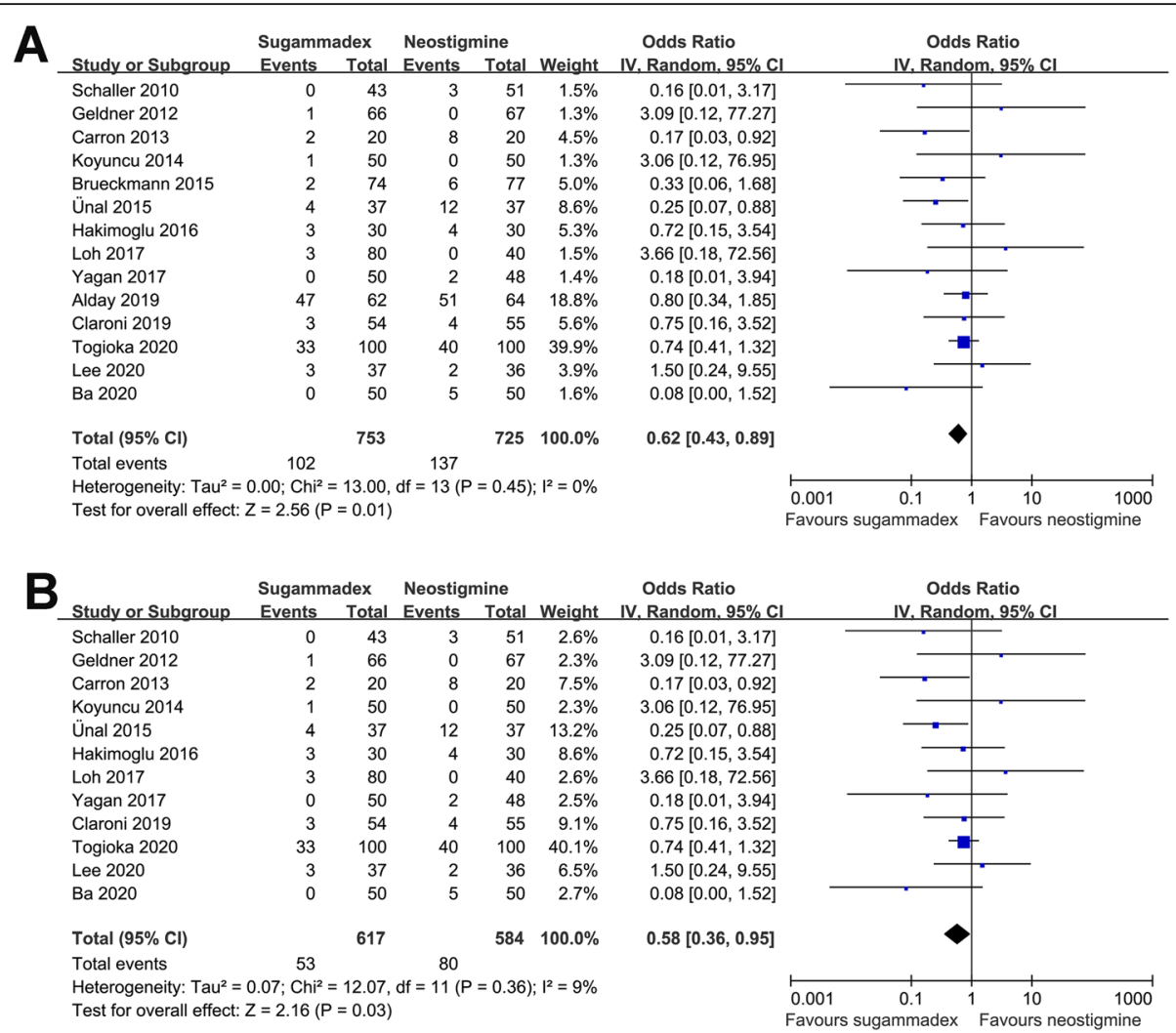

Fig. 3 Forest plots for the meta-analysis comparing sugammadex and neostigmine for the incidence of PPCs. A Main meta-analysis and $\mathbf{B}$ sensitivity analysis based on exclusion of two studies with patients who potentially had overlapping PPCs

NMB may cause pharyngeal and laryngeal dysfunction and depress pulmonary ventilation, all of which might induce PPCs (De Troyer \& Bastenier-Geens, 1979; Cedborg et al., 2014; Fuchs-Buder et al., 2016). Therefore, in view of the importance of residual NMB in the pathogenesis of PPCs, our finding suggested that sugammadex was superior to neostigmine for reduced PPCs and may reflect the faster and more complete NMB reversal efficacy of sugammadex compared with neostigmine (Hristovska et al., 2017). Moreover, the differences in pharmacology between sugammadex and neostigmine may also explain their different influences on PPCs. High-dose neostigmine may cause bronchospasm (Hazizaj \& Hatija, 2006; Ishii et al., 2012), which may therefore adversely affect the pulmonary ventilation of the patients. Additionally, neostigmine administration after adequate reversal of NMB could lead to functional disorders of the genioglossus muscle and diaphragm, which may cause obstruction of the upper airway and respiratory failure (Eikermann et al., 2008). On the contrary, by selective binding to rocuronium, sugammadex does not affect the genioglossus muscle or diaphragmatic function (Eikermann et al., 2008; Herbstreit et al., 2010). An early study showed that sugammadex (2 and $4 \mathrm{mg} / \mathrm{kg}$ ) was well tolerated and effective in patients with a history of pulmonary disease (Amao et al., 2012).
Furthermore, a recent retrospective cohort study showed that in patients with chronic obstructive pulmonary disease who underwent abdominal surgery, the incidence of PPCs was lower when sugammadex was applied for NMB reversal (Park et al., 2020). The results of our present meta-analysis are consistent with the findings of the above studies, demonstrating that NMB reversal with sugammadex is associated with fewer PPCs compared with neostigmine, and sugammadex may be superior to neostigmine for patients at high risk for the development of PPCs.

It has to be mentioned that although the $\mathrm{OR}$ is consistent with a benefit associated with sugammadex over neostigmine for the reduced risk of respiratory failure, the number needed to treat in order to prevent one case of PPC is relatively high $(\mathrm{NNT}=29.9)$ according to the pooled results of the included studies. However, prevention of PPCs is an additional benefit of sugammadex over neostigmine besides its main efficacy on the reversal of NMB. Besides, accumulating studies have shown that replacement of neostigmine with sugammadex for NMB reversal is associated with significantly reduced costs for NBM management (Carron et al., 2016b; Ren et al., 2020), which also supports the use of sugammadex in this clinical scenario. 


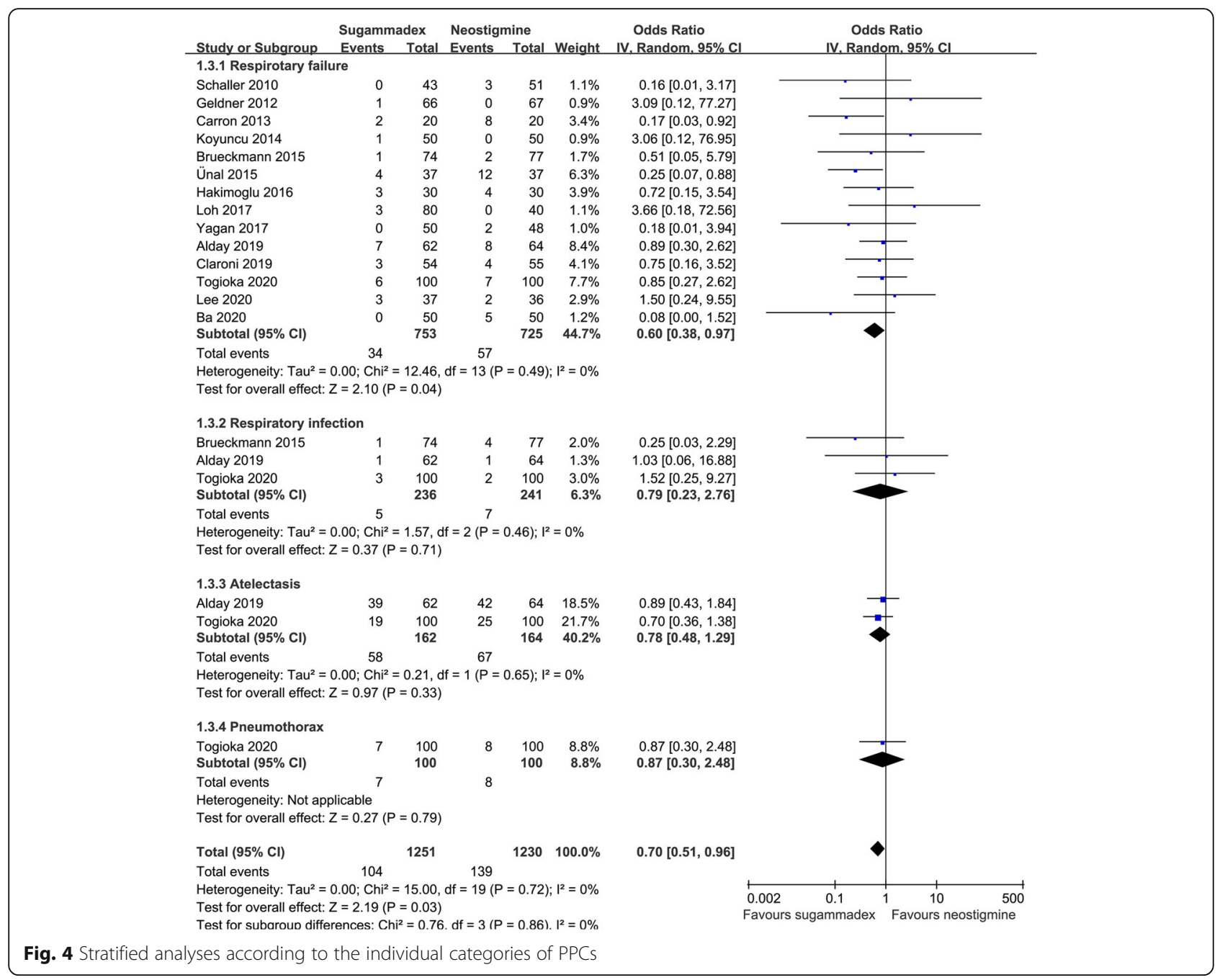

There are some limitations in our studies. First, although no statistical heterogeneity was detected among the included studies, clinical heterogeneity may exist regarding the differences in patient characteristics, surgical type, and regimens of sugammadex and neostigmine administration among the included RCTs. Moreover, we were unable to evaluate the potential influences of the above factors on the outcomes of the meta-analysis, since stratified analyses were rarely reported in the original RCTs and no access to individual patient data was obtained. Therefore, the influences of these clinical factors on the relative influences of sugammadex compared with neostigmine on PPCs or respiratory failure remains unknown. From this perspective, a meta-analysis based on individual patient data rather than that based on the study-level data is more meaningful for clinical practice. To the best of our knowledge, no studies have attempted to develop a preoperative risk assessment tool for the determination of using sugammadex or neostigmine for reversal of NMB, and none of the included studies employed such a screening tool. Therefore, further studies are needed to determine whether the potential benefits of sugammadex over neostigmine for reducing PPCs are consistent in patients with different comorbidities and in studies with different surgical procedures. Finally, as mentioned before, the superiority of sugammadex to neostigmine for reducing overall PPCs was mainly driven by data regarding postoperative respiratory failure. For other types of PPCs, including respiratory infection, atelectasis, and pneumothorax, only $1-3$ studies were included. Therefore, the non-significant results in our meta-analysis for these outcomes should be interpreted with caution, and more large-scale RCTs are needed.

In conclusion, the results of this meta-analysis based on 14 RCTs indicated that compared with neostigmine, sugammadex for reversal of NMB was associated with a lower risk of PPCs, mainly due to a lower incidence of 


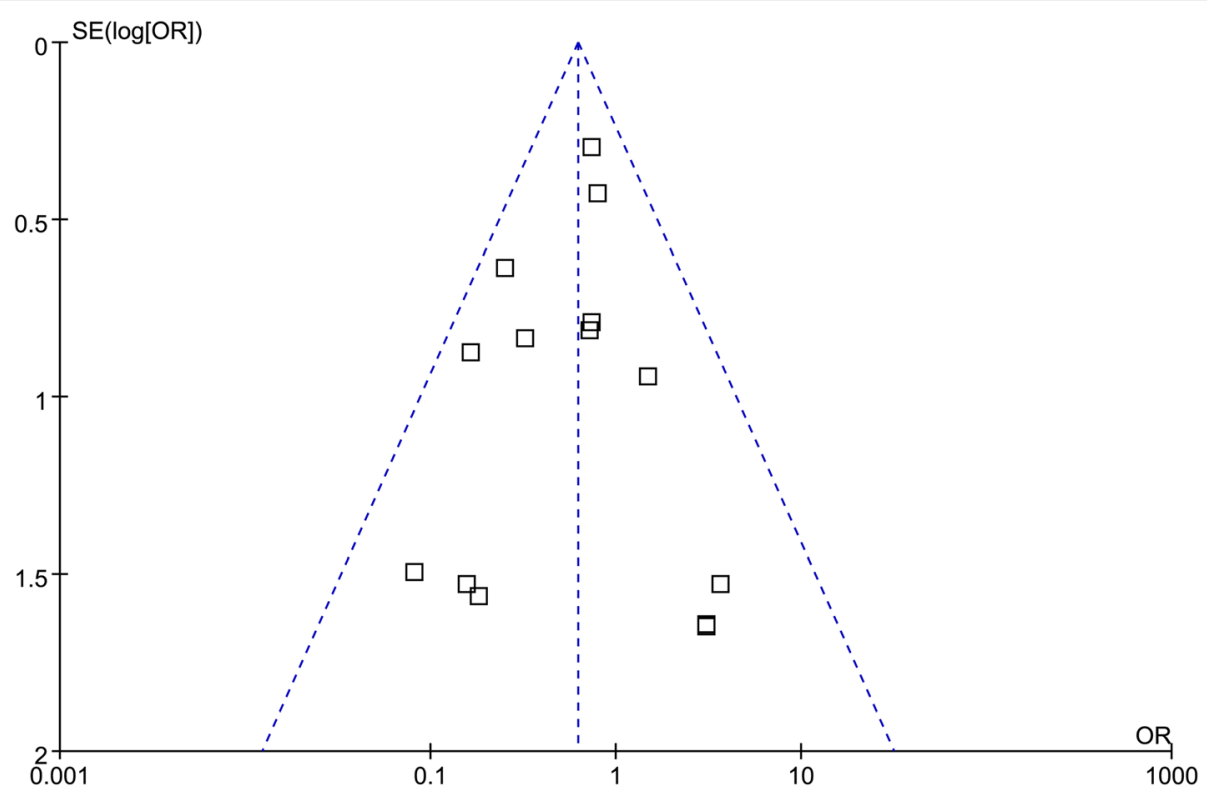

Fig. 5 Funnel plots for the meta-analysis comparing the incidence of PPCs after the use of sugammadex and neostigmine for NMB reversal. Each square represents one of the included studies, and the plots were formed based on the data of OR ( $x$-axis) and standard error of $\lg (\mathrm{OR})$ ( $y$-axis). A symmetrical of the plots could be indicated if the distributions of the squares were symmetrical according to the vertical line as the axis

postoperative respiratory failure after the use of sugammadex. These results may be attributed to the more rapid and complete NMB reversal achieved by sugammadex compared with neostigmine.

\section{Abbreviations}

NMB: Neuromuscular block; PPCs: Pulmonary complications;

RCTs: Randomized controlled trials; PRISMA: Preferred reporting items for systematic reviews and meta-analyses; OR: Odds ratio; Cl: Confidence interval

\section{Acknowledgments}

Medical writing and editorial assistance were provided by Medjaden

Bioscience Limited. This assistance was funded by MSD China.

\section{Authors' contributions}

Study design: JW and XD. Literature search: JW, ZZ, and ZJ. Hits screened and reviewed: JW, ZZ, and ZJ. Analysis of data: HL. Interpretation of data: all authors. Manuscript draft: JW, ZZ, and XD. Manuscript revision, editing, and approval: all authors. The authors read and approved the final manuscript.

\section{Funding}

The authors received no specific funding for this work.

\section{Availability of data and materials}

All data generated or analyzed during this study are included in this published article.

\section{Declarations}

Ethics approval and consent to participate

Not applicable

\section{Consent for publication}

Not applicable

\section{Competing interests}

The authors report no competing interests.

\section{Author details}

${ }^{1}$ Faculty of Anesthesiology, Changhai Hospital, Naval Medical University, 168 Changhai Road, Shanghai 200433, China. ${ }^{2}$ Department of Clinical Epidemiology and Biostatistics, Peking University People's Hospital, No. 11 Xizhimen South Street, Xicheng District, Beijing 100044, China.

Received: 7 March 2021 Accepted: 12 June 2021

Published online: 20 September 2021

\section{References}

Agha RA, Borrelli MR, Vella-Baldacchino M, Thavayogan R, Orgill DP. The STROCSS statement: strengthening the reporting of cohort studies in surgery. Int J Surg. 2017;46:198-202. https://doi.org/10.1016/j.ijsu.2017.08.586.

Alday E, Munoz M, Planas A, Mata E, Alvarez C. Effects of neuromuscular block reversal with sugammadex versus neostigmine on postoperative respiratory outcomes after major abdominal surgery: a randomized-controlled trial. Can J Anaesth. 2019;66(11):1328-37. https://doi.org/10.1007/s12630-019-01419-3.

Amao R, Zornow MH, Cowan RM, Cheng DC, Morte JB, Allard MW. Use of sugammadex in patients with a history of pulmonary disease. J Clin Anesth. 2012;24(4):289-97. https://doi.org/10.1016/j.jclinane.2011.09.006.

Ba YF, Liu YN, He SH, Li HM, Wang HR, Zhu JP, et al. Analysis of sugammadex for antagonistic neuromuscular block in patients with radical resection of lung cancer under thoracoscope. Zhonghua Yi Xue Za Zhi. 2020;100(3):213-9. https://doi.org/10.3760/cma.j.issn.0376-2491.2020.03.011.

Brueckmann B, Sasaki N, Grobara P, Li MK, Woo T, de Bie J, et al. Effects of sugammadex on incidence of postoperative residual neuromuscular blockade: a randomized, controlled study. Br J Anaesth. 2015;115(5):743-51. https://doi.org/10.1093/bja/aev104.

Bulka CM, Terekhov MA, Martin BJ, Dmochowski RR, Hayes RM, Ehrenfeld JM. Nondepolarizing neuromuscular blocking agents, reversal, and risk of postoperative pneumonia. Anesthesiology. 2016;125(4):647-55. https://doi. org/10.1097/ALN.0000000000001279.

Cammu G. Residual neuromuscular blockade and postoperative pulmonary complications: what does the recent evidence demonstrate? Curr Anesthesiol Rep. 2020;1-6. https://doi.org/10.1007/s40140-020-00388-4.

Carron M, Baratto F, Zarantonello F, Ori C. Sugammadex for reversal of neuromuscular blockade: a retrospective analysis of clinical outcomes and cost-effectiveness in a single center. Clinicoecon Outcomes Res. 2016b;8:4352. https://doi.org/10.2147/CEOR.S100921. 
Carron M, Linassi F, De Cassai A. Role of sugammadex in accelerating postoperative discharge: an updated meta-analysis. J Clin Anesth. 2020;65: 109895. https://doi.org/10.1016/j.jclinane.2020.109895.

Carron M, Veronese S, Foletto M, Ori C. Sugammadex allows fast-track bariatric surgery. Obes Surg. 2013;23(10):1558-63. https://doi.org/10.1007/s11695-0130926-y.

Carron M, Zarantonello F, Lazzarotto N, Tellaroli P, Ori C. Role of sugammadex in accelerating postoperative discharge: a meta-analysis. J Clin Anesth. 2017;39: 38-44. https://doi.org/10.1016/j.jclinane.2017.03.004.

Carron M, Zarantonello F, Tellaroli P, Ori C. Efficacy and safety of sugammadex compared to neostigmine for reversal of neuromuscular blockade: a metaanalysis of randomized controlled trials. J Clin Anesth. 2016a;35:1-12. https:// doi.org/10.1016/j.jclinane.2016.06.018

Cedborg Al, Sundman E, Boden K, Hedstrom HW, Kuylenstierna R, Ekberg O, et al. Pharyngeal function and breathing pattern during partial neuromuscular block in the elderly: effects on airway protection. Anesthesiology. 2014; 120(2):312-25. https://doi.org/10.1097/ALN.0000000000000043.

Claroni C, Covotta M, Torregiani G, Marcelli ME, Tuderti G, Simone G, et al. Recovery from anesthesia after robotic-assisted radical cystectomy: two different reversals of neuromuscular blockade. J Clin Med. 2019;8(11). https:// doi.org/10.3390/jcm8111774.

De Troyer A, Bastenier-Geens J. Effects of neuromuscular blockade on respiratory mechanics in conscious man. J Appl Physiol Respir Environ Exerc Physiol. 1979;47(6):1162-8. https://doi.org/10.1152/jappl.1979.47.6.1162.

Dubois PE, Mulier JP. A review of the interest of sugammadex for deep neuromuscular blockade management in Belgium. Acta Anaesthesiol Belg. 2013;64(2):49-60.

Egger M, Davey Smith G, Schneider M, Minder C. Bias in meta-analysis detected by a simple, graphical test. BMJ. 1997;315(7109):629-34. https://doi.org/1 0.1136/bmj.315.7109.629.

Eikermann M, Zaremba S, Malhotra A, Jordan AS, Rosow C, Chamberlin NL. Neostigmine but not sugammadex impairs upper airway dilator muscle activity and breathing. Br J Anaesth. 2008;101(3):344-9. https://doi.org/10.1 093/bja/aen176.

Fuchs-Buder T, Nemes R, Schmartz D. Residual neuromuscular blockade: management and impact on postoperative pulmonary outcome. Curr Opin Anaesthesiol. 2016;29(6):662-7. https://doi.org/10.1097/ACO.0000000000000395.

Geldner G, Niskanen M, Laurila P, Mizikov V, Hubler M, Beck G, et al. A randomised controlled trial comparing sugammadex and neostigmine at different depths of neuromuscular blockade in patients undergoing laparoscopic surgery. Anaesthesia. 2012;67(9):991-8. https://doi.org/10.1111/ j.1365-2044.2012.07197.x.

Haerter F, Eikermann M. Reversing neuromuscular blockade: inhibitors of the acetylcholinesterase versus the encapsulating agents sugammadex and calabadion. Expert Opin Pharmacother. 2016;17(6):819-33. https://doi.org/1 0.1517/14656566.2016.1145667.

Hakimoglu S, Tuzcu K, Davarci I, Karcioglu M, Ayhan Tuzcu E, Hanci V, et al. Comparison of sugammadex and neostigmine-atropine on intraocular pressure and postoperative effects. Kaohsiung J Med Sci. 2016;32(2):80-5. https://doi.org/10.1016/j.kjms.2016.01.009.

Hazizaj A, Hatija A. Bronchospasm caused by neostigmine. Eur J Anaesthesiol. 2006;23(1):85-6. https://doi.org/10.1017/S0265021505241820.

Herbstreit F, Zigrahn D, Ochterbeck C, Peters J, Eikermann M. Neostigmine/ glycopyrrolate administered after recovery from neuromuscular block increases upper airway collapsibility by decreasing genioglossus muscle activity in response to negative pharyngeal pressure. Anesthesiology. 2010; 113(6):1280-8. https://doi.org/10.1097/ALN.0b013e3181f70f3d.

Higgins J, Green S. Cochrane handbook for systematic reviews of interventions version 5.1.0: The Cochrane Collaboration; 2011. www.cochranehandbook. org. Accessed 20 Sept 2020.

Higgins JP, Thompson SG. Quantifying heterogeneity in a meta-analysis. Stat Med. 2002;21(11):1539-58. https://doi.org/10.1002/sim.1186.

Hristovska AM, Duch P, Allingstrup M, Afshari A. Efficacy and safety of sugammadex versus neostigmine in reversing neuromuscular blockade in adults. Cochrane Database Syst Rev. 2017:8:CD012763.

Hristovska AM, Duch P, Allingstrup M, Afshari A. The comparative efficacy and safety of sugammadex and neostigmine in reversing neuromuscular blockade in adults. A Cochrane systematic review with meta-analysis and trial sequential analysis. Anaesthesia. 2018;73(5):631-41. https://doi.org/10.1111/anae.14160.
Ishii K, Shibata O, Nishioka K, Tsuda A, Makita T, Sumikawa K. Effects of neostigmine on bronchoconstriction with continuous electrical stimulation in rats. J Anesth. 2012;26(1):80-4. https://doi.org/10.1007/s00540-011-1258-5.

Jammer I, Wickboldt N, Sander M, Smith A, Schultz MJ, Pelosi P, et al. Standards for definitions and use of outcome measures for clinical effectiveness research in perioperative medicine: European Perioperative Clinical Outcome (EPCO) definitions: a statement from the ESA-ESICM joint taskforce on perioperative outcome measures. Eur J Anaesthesiol. 2015;32(2):88-105. https://doi.org/10.1097/EJA.0000000000000118.

Koyuncu O, Turhanoglu S, Ozbakis Akkurt C, Karcioglu M, Ozkan M, Ozer C, et al. Comparison of sugammadex and conventional reversal on postoperative nausea and vomiting: a randomized, blinded trial. J Clin Anesth. 2015;27(1): 51-6. https://doi.org/10.1016/j.jclinane.2014.08.010.

Lee YJ, Oh AY, Koo BW, Han JW, Park JH, Hong JP, et al. Postoperative residual neuromuscular blockade after reversal based on a qualitative peripheral nerve stimulator response: a randomised controlled trial. Eur J Anaesthesiol. 2020;37(3):196-202. https://doi.org/10.1097/EJA.0000000000001157.

Miskovic A, Lumb AB. Postoperative pulmonary complications. Br J Anaesth. 2017; 118(3):317-34. https://doi.org/10.1093/bja/aex002.

Moher D, Liberati A, Tetzlaff J, Altman DG. Preferred reporting items for systematic reviews and meta-analyses: the PRISMA statement. BMJ. 2009; 339(jul21 1):b2535. https://doi.org/10.1136/bmj.b2535.

Murphy GS, Szokol JW, Franklin M, Marymont JH, Avram MJ, Vender JS. Postanesthesia care unit recovery times and neuromuscular blocking drugs: a prospective study of orthopedic surgical patients randomized to receive pancuronium or rocuronium. Anesth Analg. 2004;98:193-200 table of contents.

Murphy GS, Szokol JW, Marymont JH, Greenberg SB, Avram MJ, Vender JS. Residual neuromuscular blockade and critical respiratory events in the postanesthesia care unit. Anesth Analg. 2008;107(1):130-7. https://doi.org/1 0.1213/ane.0b013e31816d1268.

Park S, Oh EJ, Han S, Shin B, Shin SH, Im Y, et al. Intraoperative anesthetic management of patients with chronic obstructive pulmonary disease to decrease the risk of postoperative pulmonary complications after abdominal surgery. J Clin Med. 2020;9(1):150. https://doi.org/10.3390/jcm9010150.

Raval AD, Anupindi VR, Ferrufino CP, Arper DL, Bash LD, Brull SJ. Epidemiology and outcomes of residual neuromuscular blockade: a systematic review of observational studies. J Clin Anesth. 2020;66:109962. https://doi.org/10.1016/j. jclinane.2020.109962.

Ren M, Wang Y, Luo Y, Fang J, Lu Y, Xuan J. Economic analysis of sugammadex versus neostigmine for reversal of neuromuscular blockade for laparoscopic surgery in China. Health Econ Rev. 2020;10(1):35. https://doi.org/10.1186/s13 561-020-00292-x.

Schaller SJ, Fink H, UIm K, Blobner M. Sugammadex and neostigmine dosefinding study for reversal of shallow residual neuromuscular block. Anesthesiology. 2010;113(5):1054-60. https://doi.org/10.1097/ALN.0b013e31 $81 \mathrm{f4} 182 \mathrm{a}$.

Stauble CG, Blobner M. The future of neuromuscular blocking agents. Curr Opin Anaesthesiol. 2020;33(4):490-8. https://doi.org/10.1097/ACO. 0000000000000891.

Stawicki N, Gessner P. Residual neuromuscular blockade in the critical care setting. AACN Adv Crit Care. 2018;29(1):15-24. https://doi.org/10.4037/aacna cC2018384.

Tao T, Bo L, Chen F, Xie Q, Zou Y, Hu B, et al. Effect of protective ventilation on postoperative pulmonary complications in patients undergoing general anaesthesia: a meta-analysis of randomised controlled trials. BMJ Open. 2014; 4(6):e005208. https://doi.org/10.1136/bmjopen-2014-005208.

Togioka BM, Yanez D, Aziz MF, Higgins JR, Tekkali P, Treggiari MM. Randomised controlled trial of sugammadex or neostigmine for reversal of neuromuscular block on the incidence of pulmonary complications in older adults undergoing prolonged surgery. Br J Anaesth. 2020;124(5):553-61. https://doi. org/10.1016/j.bja.2020.01.016.

Unal DY, Baran I, Mutlu M, Ural G, Akkaya T, Ozlu O. Comparison of sugammadex versus neostigmine costs and respiratory complications in patients with obstructive sleep apnoea. Turk J Anaesthesiol Reanim. 2015;43(6):387-95. https://doi.org/10.5152/TJAR.2015.35682.

Won YJ, Lim BG, Lee DK, Kim H, Kong MH, Lee IO. Sugammadex for reversal of rocuronium-induced neuromuscular blockade in pediatric patients: a systematic review and meta-analysis. Medicine (Baltimore). 2016;95:e4678. 
Yagan O, Tas N, Mutlu T, Hanci V. Comparison of the effects of sugammadex and neostigmine on postoperative nausea and vomiting. Braz J Anesthesiol. 2017; 67(2):147-52. https://doi.org/10.1016/j.bjane.2015.08.003.

Zafirova Z, Dalton A. Neuromuscular blockers and reversal agents and their impact on anesthesia practice. Best Pract Res Clin Anaesthesiol. 2018;32(2): 203-11. https://doi.org/10.1016/j.bpa.2018.06.004.

\section{Publisher's Note}

Springer Nature remains neutral with regard to jurisdictional claims in published maps and institutional affiliations.

Ready to submit your research? Choose BMC and benefit from:

- fast, convenient online submission

- thorough peer review by experienced researchers in your field

- rapid publication on acceptance

- support for research data, including large and complex data types

- gold Open Access which fosters wider collaboration and increased citations

- maximum visibility for your research: over $100 \mathrm{M}$ website views per year

At $\mathrm{BMC}$, research is always in progress.

Learn more biomedcentral.com/submissions 